ELEANOR STANFORD

\title{
DEWEY DECIMAL: A CATALOGUE OF CANCER
}

oo1 Knowledge

Drop of rain hidden in a cloud moving over rocky terrain.

Birthstone glinting, finally, in the silver setting that birth carved you.

002 The book

Every morning I walk outside and read the leaves night wrote: the peas' intricate plot. The lettuce crumpled at the edges, like a page someone almost threw away, then thought the better of and re-smoothed.

o03 Systems

Limbic. Nervous. Skeletal.

Of railways, of rocks, of truth.

You can't beat the system.

Solar. Honor.

Punctuation.

Get it out of your system.

Solfeggio.

Macrobiotics.

Calendar: a way of marking

when debts fall due, when accounts

are reckoned.

"the whole creation"

Calendar: large-holed colander that won't contain.

o98 Prohibited works, forgeries, \& hoaxes

A note my son left under his pillow:

Dear tooth

fairy, I lost

my tooth

at school.

I forgot it

there, I was 
going to scrub

it to make

it shine!

Love, E.

116 Change

For a short while, I drove to work through the streets of Salvador. The sun burned my arm on the open window.

The beggars, I'd heard, would throw acid on my face to disfigure me, then steal my car. Though in my experience they were almost obscenely gentle.

Once, a man with a bucket and a squeegee bent to kiss my husband's elbow. Sometimes I looked the other way. Sometimes I gave them a handful of change.

122 Causation

Stress. Anger. Negative thinking.

Cigarettes. Pollution. Whiskey drinking.

82 Phytoestrogens. Parabens. Laurel sulfates.

Unappeased gods. The implacable Fates.

The radium brush between your lips: Undark blue.

The clocks' glowing dials. BRCA-1. BRCA-2.

Not enough: wheatgrass, self-exams, vitamin D.

Not enough jogging or broccoli.

The incinerator at the edge of your childhood town:

acrid ash filtering invisibly down.

123 Determinism \& indeterminism

Once dread of the known world led me to give away my sweaters and move to South America.

There the future was impossible to imagine as the past.

There nets were strung out in the trees, sleep a colorful impossibility.

125 No longer used-formerly Infinity

135 Dreams and mysteries

It's raining. My son and I are playing Monopoly.

Did you know you can have a dream when you're awake? Roll again. 
He moves his silver shoe dreamily three spaces.

I'm having one right now. Chance.

It's about ten animals.

157 No longer used_formerly Emotions

165 Fallacies and sources of error

Firstly, the flame of combustion is not always located in the same place.

Impurities in the sample.

Limits of the instruments.

Human error (though always present, always assumed) is not considered a source of error.

216 No longer used-formerly Evil

217 No longer used-formerly Prayer

269 Spiritual renewal

The young Orthodox women in the park touch their hair tenderly. It is silky, blow-dried, carefully styled, not their own.

386 Inland waterway and ferry transportation

386.2 I think of my grandfather, alone now, sleeping above the intercostal, its drawbridge opening and closing to let boats pass. He wakes, his lungs beating again his ribcage. He shakes the inhaler like a rattlesnake, put its metallic kiss to his mouth.

386.6 My five-year-old son announces he is changing his name to Buttercoast. For him it is still possible, with words, to inhabit someplace else entirely: to slide down that deliciously slippery bank, to reach that silken yellow shore.

391 Costume and personal appearance

The young woman behind the counter in the Black Hair Emporium, whose own coif resembles a purple waterfall-it's her own, she tells you-sells you a short blonde bob.

Putting it on is like

a mnemonic system

like slipping a letter into 
an envelope

are you the letter

or the envelope what was it

you meant to remember

Real Human Hair

the tag proclaims

399 Customs of war and diplomacy

My children are tireless generals. The skirmishes fought over unnamed territories, untenable insults to their honor.

The quiver of hesitation. The satisfying thwack of fist on back.

Sometimes I broker elaborate truces.

Sometimes I send them to the mudroom to work it out themselves.

419 Verbal language not spoken or written

A text scrolls its illuminated letters across my palm.

Where $r$ ? When $r$ u cming home?

$84 \quad$ My thick fingers fumble on the keys.

I can't figure out how to reply.

521 Celestial Mechanics

521.1 We know... that the ant keeps in her brain a map of the pattern of polarized sky light, and the pattern changes... ${ }^{1}$

521.2 There's no warranty on this thing. Look, the undercarriage is nearly rusted out. I'm not making any promises.

Hand me that wrench. No. The other one.

536 Heat

536.1 Each species of solitary beings evolves in a crucible of intense and ceaseless pressures from the environment. ${ }^{2}$

536.3 Summer is nothing. It's the chemical flush that I can't stand. Estrus. Deep-furrowed rut.

1. Bert Hölldobler, The Superorganism: The Beauty, Elegance, and Strangeness of Insect Societies

2. Ibid. 
586 Seedless Plants

586.1 The space in my son's mouth where the tooth teetered, tenuous, then fell-

586.3 Most spore capsules have a mouth, revealing inward-turning teeth. 586.5 In dry weather, the teeth open outward, and the spores disperse. 586.6 Tiny darkness surrounded by bright stars.

597 Cold-blooded vertebrates, fishes

597.2 "A thin veneer of immediate reality is spread over natural and artificial matter, and whoever wishes to remain in the now, with the now, on the now, should please not break its tension film. Otherwise the inexperienced miracle-worker will find himself no longer walking on water but descending upright among staring fish."3

597.3 The man-eating shark circles in the enormous refrigerator with transparent sides. Unicorn fish, balloon fish, porcupine fish, electric eel.

Rods and reels, harpoons, moveable flukes.

597.6 When I was twenty-two, I lived for several years on a volcanic island in the middle of the Atlantic: a stark moonscape, otherworldly outcrop.

I read and stared out at the closest island, separated by a few miles of rough water. Sometimes it was so clear I could see the window sashes on the houses. Sometimes the island was no more than a vague outline in the fog. Sometimes it disappeared completely.

597.7 I read, but I remember nothing.

It was about being pulled along, sucked under.

It was about the goat grazing on the dry hillside.

It was about the stone wall overlooking the ocean: the sharks below the water that I couldn't see; the tuna that young boys hauled up from the depths and carried on their heads, blood dripping down their temples.

634 Orchards, fruit, forestry

634.1 My mother hangs laundry from a clothesline: fruit that ripens every afternoon. The neighbors glare and mutter. She ignores them, happy to play the immigrant from some distant, less developed country who doesn't understand their language.

3. Vladimir Nabokov, Transparent Things 
634.2 In the fall, she gathers the gnarled crab apples, boils them with enough sugar to turn them into jelly.

634.3 This was our wilderness: bright sleeves pinned to the sky. A forest of steam; twisted wire branch that held the glass above the boiling vat.

638 Insect culture

What, then, are the forces that bring organisms together and subsequently transform them by altruism into superorganisms? 4

653 Shorthand

653.3 His hands move across my body-

653.4 light dashes:

aw (bog) u (bug) oo (book)

653.5 heavy dashes:

aw (law) o (boat) oo (boot)

653.6 Breath; pause; what is omitted-

653.7 others:

$\begin{array}{ll}\text { I (eye) } & \text { oi (boy) } \\ \text { ow, bow } & \text { you, few/if you } 5\end{array}$

669 Metallurgy

669.2 My father's moods seemed to come from deep within the earth. Ferrous, the dark surface glittering with tiny shards.

669.4 To understand why heat is given off when austenite changes to ferrite on cooling, think of the water-ice transformation. ${ }^{6}$

699.5 It is extremely useful to have an elementary understanding of two topics: solutions and phase diagrams.7

669.7 Our [sic] bodies often contain more than one valuable metal. ${ }^{8}$

4. Hölldobler, ibid.

5. The Joy of Pitman Shorthand, http://pitmanshorthand.homestead.com/

BasicsofPitman.html

6. John D. Verhoeven, Steel Metallurgy for the Non-Metallurgist

7. Ibid.

8. "Metallurgy," Wikipedia, http://en.wikipedia.org/wiki/Metallurgy 
681 Precision instruments \& other devices

"Melvil Dewey as a boy split wood, pastured cows and did other chores for the pennies and nickels offered by farmers. The meagre earnings he saved, until he had enough for an unabridged dictionary, and he walked ten miles to Watertown, N.Y. to buy it." 9

For the thrill of the onionskin pages, the lovely heft of it.

He held it in both arms: divining rod, compass pointing him home.

742 Perspective (graphical)

A note from my son, age seven:

Dear Mo

mmy,

Where

do you

go when

I'm away?

748 Glass

Stained tumbler. Drinking vessel. Sea-

glaze. Amphetamine clarity: Enclose me.

Pale Depression-patterned cake plate.

Compound solidified from a molten state.

Each hour's slow vitreous glister.

Mirror. Windowpane. Barometer.

753 Symbolism, allegory, mythology, legend

The women call to their children at the playground: Destiny, be careful on the swings!

Moishe, put down that stick!

Brooklyn, come back!

787 Stringed instruments

My son's hands hover above the keys: soft moths

drawn to the burning song.

9. “Dr. Melvil Dewey Dead in Florida," New York Times, December 27, 1931 
Is this what Joe Zawinul meant

by Mercy. Mercy. Mercy.

912 Graphic representations of earth

The surgeon leaves strange topographical lines on my mother's body.

His magic marker once the intention of his magic mind.

Now the shadow of a rain cloud moving over her.

999 Extraterrestrial worlds

When she comes up briefly from the anesthesia, drowsy and tender, I am lying at the foot of her bed: a tether; and her a plumb, tossed out, still falling, reckoning the depths. 